\title{
Space Making in the Global South: Lessons from the GCC-Mercosur Agreement
}

\section{Silvia Ferabolli*}

\begin{abstract}
This article proposes a revised approach to the mainstream definition and understanding of the term 'Global South' by anchoring its meaning in a relational view of space. Secondly, it presents the GCC-Mercosur agreement as a case study that illustrates the obstacles involved in the making of spaces in the Global South. The main research question addressed here is: Why has the GCC-Mercosur framework agreement failed to materialize into a meaningful economic space? This question will be answered through David Harvey's theoretical insights and Doreen Massey's relational approach to space, as well as post-structural geography. This article argues that the promise of increased trade and investment was the basis on which the GCC-Mercosur economic space was designed, but the narrowness of the framework agreement's scope and the socio-political relations organized around it have not been able to sustain or strengthen this Global South space. This study employs discourse analysis as its main methodological technique, grounded on a Foucauldian understanding of the empirical properties of discursive activities. It concludes by advocating for the need to incentivize a broader engagement of civil society in the processes of Global South space making.
\end{abstract}

Keywords: Global South; relational space; GCC-Mercosur Agreement; South-South relations; Arab-Latin American relations.

\section{Introduction}

On 10 May 2005, the member states of the Gulf Cooperation Council (GCC) - Bahrain, Kuwait, Oman, Qatar, Saudi Arabia and the United Arab Emirates - and those of the Southern Common Market (Mercosur) - Argentine, Brazil, Paraguay and Uruguay signed a Framework Agreement on Economic Cooperation between the two organisations. Fifteen years later, this agreement remains exactly what it looked like in 2005 - a mere document that defines the terms for future negotiations between the two blocs. The absence of mutual developments between them after so long raises the puzzling question

* Federal University of Rio Grande do Sul (UFRGS), Porto Alegre-RS, Brazil; silvia.ferabolli@ufrgs.br. ORCID iD 0000-0003-0589-3998. 
of why this framework agreement has failed to materialize into a meaningful economic space? This is the question that guides this research and that aims at contributing to the development of the field of Global South studies by discussing the controversial case of South-South relations represented by the GCC-Mercosur agreement, within the framework of the relational approach to space.

The Framework Agreement on Economic Cooperation between the GCC and Mercosur can be narrated as part of the genealogy of Arab-Latin American relations (see Galindo 2013; Brun 2015; Pinto 2016; Ayuso et al 2018). ${ }^{1}$ This genealogy dates back to a period in which Arabic-speaking Muslim Africans were brought to the so-called new world through the horrendous slave trade that began in the $16^{\text {th }}$ century. Likewise, from the end of the $19^{\text {th }}$ century up to the middle of the $20^{\text {th }}$ century, massive non-coercive migrations of Arabic-speaking Christian Levantines to the Americas began to take place. Another possible genealogy of the GCC-Mercosur relations locates them within the array of the global changes witnessed in the first decade of the new millennium, which revealed that intra-South trade, intra-South capital flows and intra-South migrations were gradually (and asymmetrically) becoming the driving forces of the global economy. One could argue that this momentum is the efficient cause (in the Aquinian sense) for the repositioning of key states of the Global South within the international system, most notably, of the BRICS members, but also of the MINT, Civets and the $\mathrm{N}-11,{ }^{2}$ to mention the most frequently cited acronyms in the literature.

In South America, Brazil was at the height of its quest for being awarded a seat at the global decision-making table of the UN Security Council, perceived as necessary in the country's understanding of a necessary path to be taken in order to strengthen its leadership in the region. In the Arab world, September 11 ushered in a whole new set of restrictions (and insecurities) for Arab Gulf States' global investments, making the Arab region a more attractive (and secure) place for these states to invest their oil-derived capital. It was at this particular intersection of global and regional contexts that the former Brazilian president Luiz Inácio Lula da Silva, during a visit to the League of Arab States' headquarters in December 2003, proposed the institutionalization of Arab-South American relations. In March 2005, the first summit of Arab-South American Countries (ASPA) was held, paving the way for various forms of cooperation between these two regions (see Farah 2014; Ferabolli 2017). These included the Framework Agreement on Economic Cooperation between the GCC and the Mercosur, the blueprint of what is here called the GCC-Mercosur space.

In order to address the proposed research question and to frame it in the realm of Global South studies, I will begin by reviewing the literature about the Global South in the light of David Harvey's tripartite division of space and explain the relevance of the case study hereby analysed in order to provide a broader understanding of the meanings traditionally associated to the South. Next, I will stress the conceptual relevance of the relational approach to space to this investigation, present my main sources and explain how they were interrogated. Afterwards, I will demonstrate how the promise of increased trade and investment were the bases over which the GCC-Mercosur economic space was 
designed, and how the narrowness of both the scope of the framework agreement signed in 2005 , as well as the relations that are organized around it, have not been able to sustain this space, which remains yet to be achieved. Finally, I discuss the implications of this study for the broader debate on space making in the Global South.

\section{The Global South as the space of South-South relations}

I invite the reader to look at the below suggested post-Cold War updated version of the Brandt Line - which in the early 1980s proposed a division of the globe established along the categories of the developed North and the developing South (instead of the capitalist West and the communist East) - applied on the Gall-Peters projection of the world map.

Figure 1 - Brandt Line

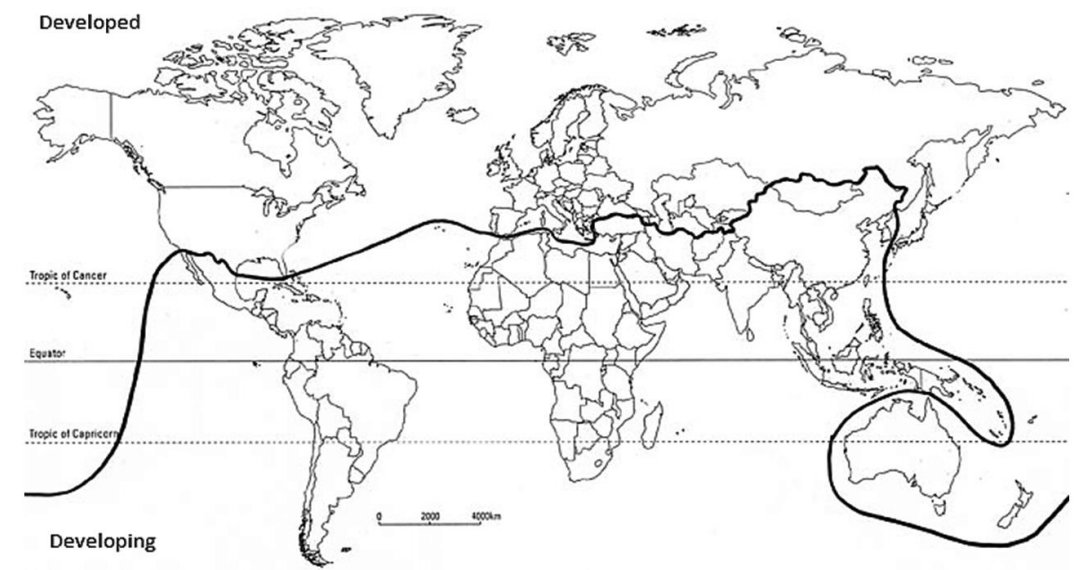

Source: Internet Geography (n.d.).

Figure 2 - Post-Cold War updated version of the Brandt Line

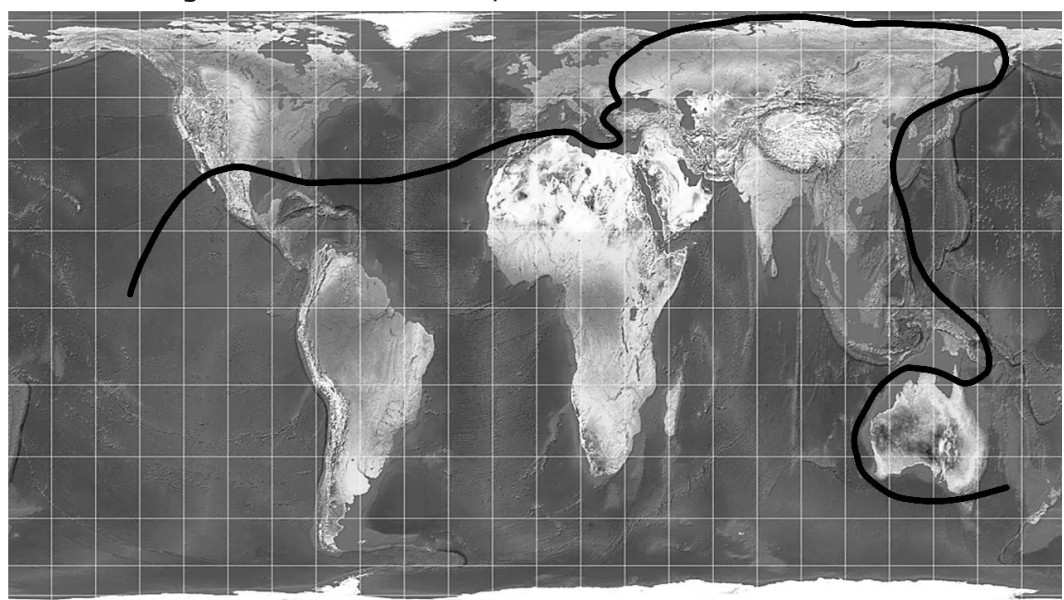

Source: Created by the author. Image is the Gall-Peters Map Projection by Tobias Jung. 
Is it possible not to reach the conclusion that the South is colossal? This category entailed Latin America and the Caribbean, Eastern Europe, Africa, South Asia, Southeast Asia, Central Asia, China, the Middle East, and the Persian Gulf. As such, the South easily dwarfs the North. This might be the reason why it has been argued that if 'the East is a career, as Benjamin Disraeli (1847, cited in Said 1978: xiv) would assert, the South is also becoming one. The concept of the South that has been generating heated academic debates, has inspired the creation of institutions designed for research, publishing and networking, and became fashionable in foreign policy-making circles. However, what the South is, and where it is located are questions that have been begging accurate answers but have nonetheless continued to receive vague responses. If the signified 'North' has consolidated its association with the signifier USA-Western Europe-Japan, even in spite of a lack of generalized agreement about it, the South still has a long road to travel before signifying practices guarantee that this mental concept finds its material correspondent in any meaningful way.

As far as IR scholarship on the Global South is concerned, this concept is typically understood as a 'something' and/or a 'somewhere' - a claim I do not fundamentally refute. I do argue, however, that this approach is incomplete. In Social Justice and the City (1973), David Harvey proposed that 'space' could be approached in absolute, relative and relational terms. Overall, IR scholarship has held closely to the notion that the Global South is a well-defined entity composed of developing countries. In this sense, the South would be an absolute space, or a 'thing in itself [possessing] a structure which we can use to pigeon-hole or individuate phenomena' (Harvey 1973: 13).

This perception led Grovogui (2011: 178) to state that he refers 'to the Global South as an object, a thing, and therefore an "it" on account of its unifying properties and in the interest of efficiency. In the same fashion, both Dargin and Braveboy-Wagner described the Global South as an assemblage of some specific countries. This assumption becomes clear in statements such as '[this book] seeks to explain the rising geopolitical, economic and cultural power of the countries that make up the Global South' (Dargin 2013: v), and 'international institutions have been profoundly important for those countries that we now refer to as the "global south" (Braveboy-Wagner 2009: xiii). Alden, Morphet and Vieira (2010: 7) also described the Global South as an 'it' that 'acts', when they stated that 'the primary locus of action for the South is found in issue-based foreign policy pressure groups, traditional South-South organizations, such as the G-77 and NAM.' Those who embrace the idea that the Global South is a delineated and well-defined entity composed of developing countries end up also defining it as the place in the world where these developing countries are located. This was the case as Braveboy-Wagner (2016:2) affirmed that, 'some countries other than the traditional "powers" have emerged as important players in the past few decades. Many of these countries are from the so-called "global south."”

The South as an absolute space seems to follow the Brandt report's portrayal of the world: an irregular line drawn around a latitude of 30 degrees north of the Equator dividing the rich North and the poor South according to their gross domestic products (GDPs). The characteristic irregularity of Brandt's line purposefully aims to tweak geographical exceptions to fit them into his conceptual world map in order to arbitrarily maintain the 
separation as it is, such as forcing Mexico into the South and Australia and New Zealand into the North. However, the divide between North and South could never be captured by a more precise division of the Earth's hemispheres, inasmuch as the Equator's imaginary line locates the whole of Asia and the Middle East, and most of Africa's territory, in the North. This 'real map', however, 'is one in which the (former) colonial powers are located exclusively in the northern hemisphere' (Grovogui 2011: 178).

Figure 3 - Brandt Line

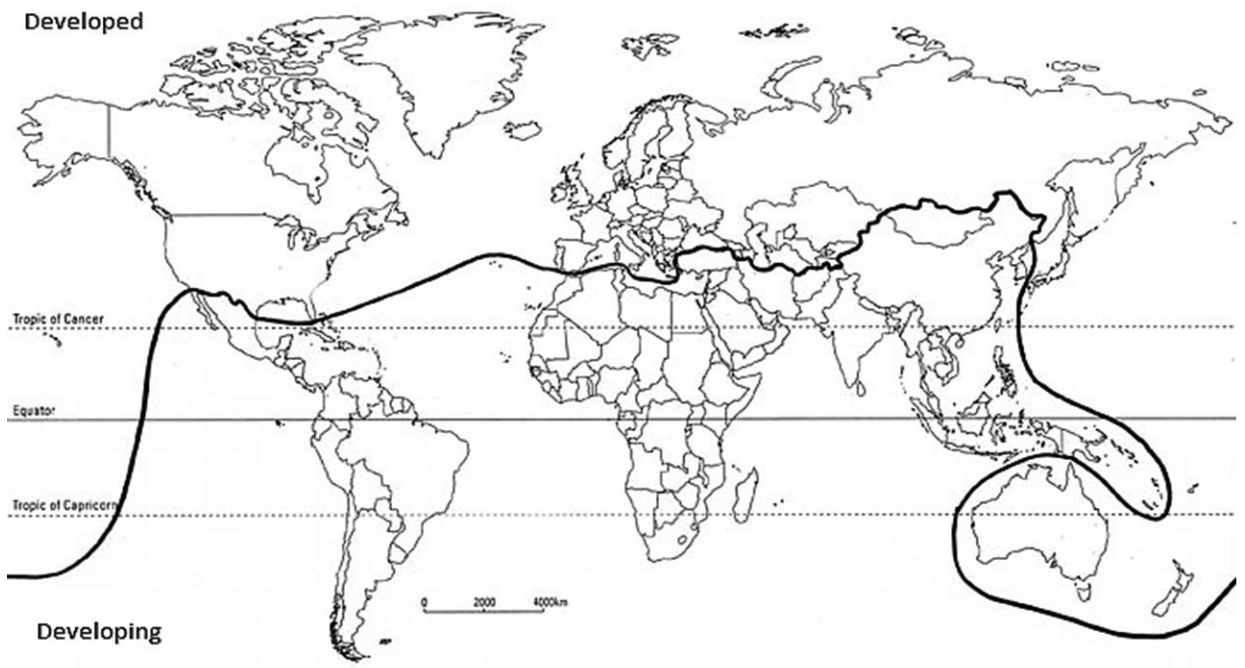

Source: Internet Geography (n.d.).

Figure 4 - Equator's Line

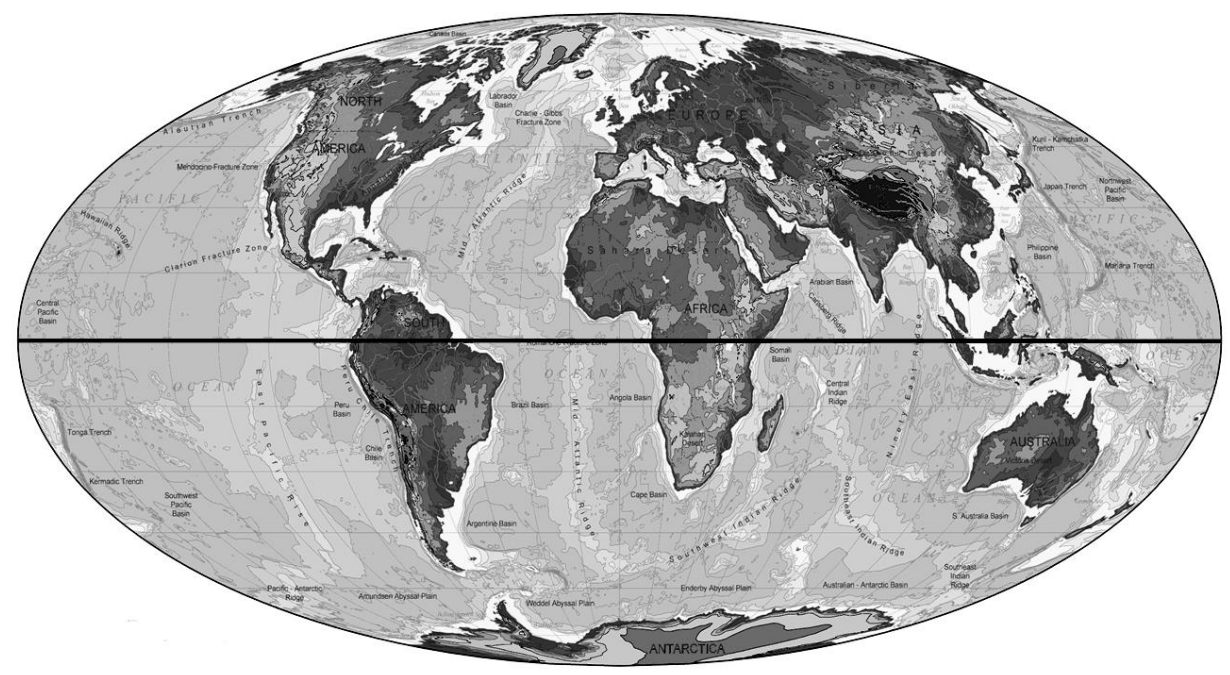

Source: Britannica (n.d.). 
The absoluteness of the North is what makes IR scholarship on the Global South also appreciate it as a relative space, to be understood, in Harvey's proposition, 'as a relationship between objects that exists only because objects exist and relate to each other' (Harvey 1973: 13). In this sense, the South exists in relation to the North. In other words, the South is conceived in opposition to the North - that is, the South that perceives the world as dominated by the rules of the North and that wants to challenge it. In this regard, the meaningfulness of the term 'South' resides in its capacity to become 'a source of national and transnational identity [...]. It is an identity that presumes a "North" (Alden et al 2010: 3). Similarly, for Hurrell (2013: 213),

[A] central part of the problem of global order from mid-19 ${ }^{\text {th }}$ century was the struggle of the non-Western world, the Third World or later the Global South against what was widely understood as the western dominance of the international system - what Hedley Bull termed the 'revolt against western dominance.'

This is how Braveboy-Wagner (2009: 3) also understood the intention and meaning behind this term, which for her consists of 'a group of countries that [...] continue to see their problems, and to construct their narratives, quite differently from those of the developed nations of Europe, North America, and Asia.' Likewise, for Gray and Gills (2016: 558)

$[\mathrm{R}]$ ecent economic and diplomatic achievements of several key countries of the global South [...] has given impetus to increasing debate and consideration of the potentialities (and pitfalls) of a new phase of challenge or construction of alternatives to the hegemonic and neo-colonial politics of the global North.

At a point in time, the BRICS epitomized this understanding of the South as a relative space. ${ }^{3}$ While not denying that the Global South can be understood as an absolute and a relative space, as the terms are not necessarily mutually exclusive, I advance the idea that the conceptual and political significance of this concept will only be fully revealed when it is approached through the lens of relational space. Following Leibniz's insights on this subject matter, Harvey explains that in 'the relational view of space, there is no such thing as space outside of the processes that define it. Processes do not occur in space but define their own spatial frame' (Harvey 2004: 4). In this sense, the South is neither a container for developing entities, nor for the processes that constitute institutions and organizations for cooperation, or movements and acts of resistance against the North. Instead, it is precisely when these entities and processes combine in their relations with each other that the South is constituted as such.

Furthermore, the relations that fundamentally constitute the spatial frame defined by the word 'South' are South-South relations. Here, the South is not only that which stands against the North, but also that which stands by itself, giving rise to the following question: Does the South exist without these relations? The short answer would be that 
yes, the material South does - meaning the geographic land south of the Equator line. A South that has materiality, but no life to invigorate it; ${ }^{4}$ therefore, a meaningless South. ${ }^{5}$ In post-structural parlance, the fact that our eyes see a delimited Global South is an effect of South-South relations. Thus, the Global South is the sum of existing and potential relations between the various units of the South, and the GCC-Mercosur space is one of these spaces of South-South relations that in effect constitute the Global South as such.

Analyses of South-South cooperation make up the cornerstone of Global South studies. This scholarship tends to concentrate its intellectual efforts mainly on examining successful examples of cooperation between developing countries, especially in multilateral settings and institutions. It also tends to concentrate in cases such as deciding whether Chinese endeavours in Africa or Latin America constitute cooperative relations between Southern countries or whether these relations are mere reproductions of North-South relations (see for example Woods 2008; Rich and Recker 2013; Stuenkel 2013; Cheru 2016; Muhr 2016; Bergamaschi et al 2017). This scholarship is limited by the normative expression 'South-South cooperation,' leading us to think that the constitutive relations of the Global South as a space are (or should be) necessarily cooperative. This expression should be replaced by 'South-South relations', because this term would place us within a framework of thought that is thoroughly aware of the Foucauldian maxim that all relations are relations of power. And as far as space making is concerned, all 'spatial relations are also power relations' (Murdoch 2006: 23).

In that sense, the Global South is a space in which relations unfold between inevitably diverse states and other political entities, social movements, formal and informal organizations, and even individuals from the former colonized areas of the world and/or from peripherical areas of the international capitalist system. Thus, the diversity between the entities that constitute the South not only generates distinct and sometimes conflicting interests. It can also produce unequal outcomes. Thus, the relations developed between them are necessarily power relations. ${ }^{6}$ How these relations enact the Global South should be given precedence in our studies over the search for where the South is located, or for what defines a country or a region as Southern.

The Global South is a concept whose meaningfulness does not reside in its capacity to represent a something or a somewhere ${ }^{7}$ - but more importantly, in its ability to resonate. In other words, the Global South significance lays in its ability to assist us in decoding global space from a different perspective, thus changing the way we think about and act in the world. Locating the members of the GCC in the South is especially illustrative of this argument.

Authors such as Terterov, Vallet and Nocente (2013), who claim that a country like Saudi Arabia cannot be considered as a part of the South 'given the development levels that the Kingdom has been able to reach with the help of oil incomes', and those who sustain that a club of super-wealthy states like the GCC does not 'fit' the concept of Global South, make this argument based solely in these countries' GDP and in the extravagant display of their elites' wealth. However, the very formation of most Gulf oil monarchies around the needs of the global oil industry, their uttermost economic dependence solely 
based on the exportation of this commodity and their extreme reliance on foreign military protection to guarantee that the invariably unelected GCC rulers remain in power, are factors that render them a resemblance much more like some of their Latin, Asian and African counterparts than their European or North American ones. Besides,

[T] he fact that the khaleeji capital (capital from the Gulf) is profit-seeking and that its investments in the Middle East and other Muslim countries come with a whole set of political conditionalities should not obliterate the importance of the established record of South-South cooperation driven by the AGS [Arab Gulf States], especially as far as the role that Arab and Islamic institutions play in promoting development in Africa, Asia and the Middle East. Arab official development assistance (ODA), foreign direct investment (FDI), development banks and migration flows belong to the realm of South-South cooperation in the same way that they belong to the realm of South-South power relations (Ferabolli 2019).

In addition to the above mentioned (mostly) state-led relations between the GCC states and other developing countries, ${ }^{8}$ it is essential to appreciate that when the space constituted by the GCC is acknowledged as a part of the Global South, we also allow the integration of the Arab Gulf's indigenous social movements, political activists and critical voices into the Southern narratives. This entails decoding global space differently and this is the crucial meaning of the Global South as a concept with political resonance. The fact that the GCC rulers often frustrate our expectations regarding the way the political elite of the South should behave cannot prevent us from recognizing that they are part, and as such, a parcel of the Global South as the space of South-South relations. When high representatives of the GCC and Mercosur get together to sign a framework agreement on economic cooperation, they are - intentionally or not - engaged in the constitution of a new space of the South, and this process is worth being studied.

As for the obstacles involved in the making of spaces in the Global South, these are as immense as the South itself, ranging from logistics and infrastructure to the absence of proper bureaucracies and institutions capable of sustaining external relations at the global scale. This is especially true when the actors involved are particularly far apart from each other and without a previous history of economic, political or cultural connections, hence the relevance of the case study proposed here. The obstacles faced by the GCC-Mercosur agreement to materialize into a meaningful economic space can provide clues for thinking about other inchoate Southern spaces and examining them, such as in the case of the African Continental Free Trade Area and the ALBA Peoples' Trade Treaty.

\section{Relational space making}

This study combines general knowledge about the Global South as a space forged by the (power) relations between states and other political entities from the former colonized 
areas of the world and/or from those in the peripheries of the international capitalist system, with empirical knowledge about the GCC-Mercosur space.

The contribution here is an in-depth study of a single unit that can shed light on the process of space making in the Global South instead of a sample seeking to 'represent a population of cases' and/or 'pertaining to a broader class of units' (Gerring 2004: 344; see also Geddes 1990). Therefore, whilst this study does not offer a 'specific proposition that might be applied across a larger set of units' (Gerring 2004: 345), its utility is derived from its potential to inform scholars, policy makers and practitioners about the state of affairs between the GCC and Mercosur, and serve as a point of departure or reference for future analyses of Southern spaces in the making.

Choosing the relations between the GCC and Mercosur as a case study of how the Global South is constituted as a space by South-South relations may be polemical, but it also is highly effective. It is controversial not only because locating the GCC in the South is not unanimous, but more importantly, due to the fact that the GCC-Mercosur economic space has not yet - and may never - materialize. However, Murdoch's (2006: 20) post-structuralist approach to geography proposes that 'some attention must be paid to spaces that do not emerge, to the sets of relations that fail to gain any kind of spatial coherence.' Why has the GCC-Mercosur economic space failed to materialize so far, as to gain any kind of spatial coherence? One could argue that, since this space is constituted by two seemingly discrete subregional blocs made up of sovereign entities, we could just delimit its physical borders following the demarcation lines of the Mercosur member states and those of the GCC and - voilà! - we would then have a material-territorial (or an absolute) GCC-Mercosur space. However, to embed the definition of space into territoriality alone renders one's analysis static and incomplete.

There is much controversy regarding the alleged opposition between the positions that conceive of territory as synonymous with space and those that conversely claim space is nothing but relations - which directly relate to my previous interpretation of absolute, relative and relational conceptions of the Global South as a space. Although I do not delve into this territorial-relational controversy, the analysis developed here is aligned with the latter relational point of view. As defined by Doreen Massey in For Space (2005), the relational approach does not necessarily exclude the dimensions of territoriality, but instead makes interrelations, multiplicity and ongoingness the centre of its quest for understanding space. For Massey (cited in Murdoch 2006: 20), 'space is a product of interrelations [which] run through differing spatial scales from the very local to the global and to all points in between.'

When this reasoning is applied to the case of the GCC-Mercosur space, we can think of the following constellation of interrelations: the poultry produced in Passo Fundo, a rural municipality of Brazil's Rio Grande do Sul state (local), is exported to the Gulf states (regional). In cases as such, import regulations are determined by the laws of each GCC country (national), yet the GCC-Mercosur Framework Agreement seeks to standardize, regularize, promote and facilitate commerce (interregional and international) which, intentionally or not, fosters the notion of 'important' and 'vital' South-South trade (global). 
In short: the interrelations that occur here at different spatial scales, as Massey argues (local, national, regional, interregional and global), are contained inside of the object of this study: the GCC-Mercosur space.

Massey (2005: 9) also saw space and multiplicity as co-constitutive: 'Without space, no multiplicity; without multiplicity, no space.' Finally, she affirmed that space is an 'open and ongoing production' (Massey 2005: 55). This statement means that 'there are always - at any moment "in time" - connections yet to be made, juxtapositions yet to flower into interaction (or not, for not all potential connections have to be established), relations which may or may not be accomplished' (Massey 1999: 2). This line of reasoning, in turn, connects directly with Harvey's insights on Whitehead's concept of permanence: 'the process of place formation is a process of carving out "permanences" from the flow of processes creating spaces' (Harvey 1996: 261). Spaces are then '(provisionally) stabilized out of complex, open-ended processes' (Murdoch 2006: 20). When our eyes see a discrete space (like the 'European space, for example), this is due to the very momentary stabilization of processes and relations, and these are what Harvey calls 'permanences', given that 'no matter how solid they may seem, [they] are not eternal: they are always subject to time as "perpetual perishing". They are contingent on the processes that create, sustain and dissolve them' (Harvey 1996: 261). Precisely, in the following section, I will describe the processes that created the GCC-Mercosur space, demonstrate how the scarcity (lack of multiplicity) in the entities and processes combined to constitute the GCC-Mercosur space have not been able to sustain its consolidation, and suggest that this is leading to the dissolution, rather than to the evolution, of this economic space in the South.

Within the relational frame of reference developed by Harvey, the processes that are at the heart of space formation are relations, interrelations and interactions. Therefore, following Massey's and Harvey's conceptions on relational space making, it is assumed that relations, interrelations, interactions and correlations are practices that constitute space, since it is through them that space formation is performed and acquires the semblance of materiality and of permanence. These practices can be approached as discursive activities, that is, they can be analysed as discourses, understood 'as practices that systematically form the objects of which they speak' (Foucault 1982: 49).

Therefore, the GCC-Mercosur space is the performative materialization of the discourses embodied in the text of its framework agreement, in the acts and speeches of those involved in (and left out of) the construction of this potential economic space. It is likewise performatively materialized in the data produced by specialized agencies and by organizations on trade and investment between its members states, and in the declared expectations (and acknowledged frustrations) regarding the agreement signed in 10 May 2005, that laid the foundations of one of the largest free trade areas in the Global South.

In order to analyse the discursive practices that have both instigated and dissuaded the constitution of the GCC-Mercosur space, I propose the method of discourse analysis anchored on the empirical properties of discursive activities as advanced by Foucault in The Archaeology of Knowledge (1982), in 'The Order of Discourse' (2020), and in 'Society Must Be Defended': Lectures at the College de France, 1975-1976 (2003). Thus, I will consider 
what is performed, said, written, produced and reproduced, yet also what is not said and is rather despised, silenced or excluded concerning the relations between the GCC and Mercosur as discourses that can be analysed. My sources will be interrogated with the aim of addressing the three closely interrelated following questions: i) Why was an agreement between the GCC and Mercosur proposed in the first place?; ii) What were the terms of this agreement - who/what was included and excluded?; and iii) What are the consequences of these inclusions and exclusions? The answers to these questions will allow me to understand why the Framework Agreement on Economic Cooperation between the GCC and Mercosur has so far failed to materialize into a meaningful economic space.

My main source is the very text of the GCC-Mercosur framework agreement, signed by their respective representatives. I also examine secondary data obtained from official reports issued by the Arab Investment \& Export Credit Guarantee Corporation (Dhaman), the United Nations Economic Commission for Latin America and the Caribbean (ECLAC), the United Nations Economic and Social Commission for Western Asia (ESCWA), and the Inter-American Development Bank (IDB), as well as information gathered from the World Integrated Trade Solution (WITS) software databases. Semi-structured interviews were conducted with the coordinator of the Brazilian Ministry of Foreign Affairs' Trade Negotiations Division with the Middle East, Africa and Asia, and with representatives of the Arab-Brazilian Chamber of Commerce. At different stages of this research project, I sought to conduct phone and email interviews with several Gulf embassies and consulates across South America, as well as with the office of the General Union for the Chambers of Commerce, Industry and Agriculture in Arab Countries (GUACCIT) and with the headquarters of both the GCC Secretariat in Riyadh and the Mercosur Secretariat in Montevideo. Nonetheless, these interviews were never conceded by the authorities in question. It is noteworthy that neither the Mercosur nor the GCC official websites make available any data on economic, political or cultural exchange between the two blocs. It is also to be noticed that none of the ten members engaged in this endeavour display nor provide any information on the bilateral relations carried out among them within the scope of the agreement in their foreign ministries' official websites. Eventually, I obtained scarce data and dispersed information, but also surprisingly instructive insights on the making of spaces in the Global South.

\section{The making and the unmaking of the GCC-Mercosur space}

The Southern Common Market and the Gulf Cooperation Council are two sub-regional constructions that stemmed from larger region making processes. Although the Treaty of Asunción of 1991 established Mercosur, its member states were - and still remain - members of the Latin American Integration Association (ALADI), created in 1980 to replace the 1960 Latin American Free Trade Association (ALALC). Even though ALALC was born from the influence of efforts developed by the United Nations Economic Commission for Latin America and the Caribbean (ECLAC) from 1948 onwards, the discourse of promoting integration among the peoples of Latin America dates back to the early $19^{\text {th }}$ century 
and to Simón Bolívar's struggle to create a union of independent nations in Hispanic America following its independence movements.

Similarly, the GCC is essentially made up of six out of the twenty two members of the League of Arab States (LAS), whose establishment in 1945 was an outcome of the long trajectory of Arab nationalism developed during the early decades of the $20^{\text {th }}$ century, and that furthered the idea that Arabs constituted a nation which deserved to be in some way united. The reasons that led the GCC to launch its own regional project in 1981, without ever leaving the LAS, are widely-known. Among these are the fact that the oil monarchies needed to join forces against the militant and revolutionary Iranian neighbour and the ambitious and heavily armed Iraqi brother, in addition to the dangerous Arab nationalist discourse that saw the Gulf oil wells as legitimate sources of funding for Arab development.

Another important reason for the constitution of the GCC is one that closely approximates it to Mercosur's founding impetus: the recurrent obstacles faced by the League of Arab States in promoting a Free Trade Area within the Arab region to advance the establishment of a Customs Union between its member states led the GCC states to seek a smaller space for manoeuvre. Similarly, when Argentina, Brazil, Paraguay and Uruguay founded Mercosur, both ALALC and its successor ALADI had not yet managed to promote the creation of a long-sought, all-encompassing Latin American economic integration program. The reduction in scale from the thirteen ALADI members to only four ${ }^{9}$ states enabled the construction of a more manageable space in South America; as of today, Mercosur is a Customs Union undergoing a consolidation process, with some Common Market features. The status of a Customs Union was also achieved by the six member states of the GCC in 2015.

These sub-regional spaces acquire the semblance of a 'bloc' and are therefore recognized as such. This is how the Arab-Brazilian Chamber of Commerce explains the reasons behind the establishment of a framework agreement between the GCC and Mercosur during the first ASPA Summit in 2005: 'because they're both Customs Unions, agreements will tend to be signed between these blocs' (CCAB 2018).

Among other things, the ASPA Summit envisioned mechanisms to boost economic cooperation and commercial exchange between the twelve member states of the Union of South American Nations (Unasur) and the twenty-two members of the Arab League. However, considering that these two regional organizations are still struggling to develop these very mechanisms within their respective regional spaces, the prospects of success in Arab-South American economic inter-regionalism at the time of the first ASPA Summit seemed a mirage, rendering the GCC-Mercosur pursuit of a separate agreement between leaner - and presumably, more agile and efficient - blocs comprehensive, to say the least. Surprisingly, Arab-South American trade nearly tripled in the decade after the first ASPA summit, rising from just over US\$ 13 billion in 2005 to almost US\$ 35 billion in 2015 (Ministry of Foreign Affairs [Brazil] 2015). The GCC-Mercosur framework agreement, on the other hand, was never fully implemented.

To make sense of this state of affairs, one should keep in mind that 'the relational making of space is both a consensual and contested process' (Murdoch 2006: 20). In that sense, 
even though the GCC-Mercosur agreement was envisioned precisely because there was an initial consensus over the opportunities that could arise from this potential economic space, it has simultaneously been a contested process throughout its developments. From its inception, the consensus has been forged around the agricultural axis which sustains that 'it's a fact that a synergy of interests exists, especially in the agricultural sector; both because of a need of Mercosur to improve its logistical infrastructure, reducing the costs of production, and of the GCC countries to guarantee their food security', as noted by the Arab-Brazilian Chamber of Commerce (CCAB 2018).

Mercosur countries indeed 'have been the most important economic partners of the GCC states in Latin America' (Viramontes 2012: 38). This relates directly to food security issues in the GCC. Its member states are among the largest food importers in the world and they are also among the most important destinations for Mercosur agribusiness exports, especially those coming from Brazil and Argentina. It is estimated that 'between 80 and 90 percent of existing food supply in GCC countries is imported' (Hubert 2017). Yet, this does not necessarily mean that the region is in a situation of food insecurity, given that it possesses enough oil reserves to be able to spend only 2 to 3 percent of its international reserves with food imports (Sophia 2015). These resources available for food imports are precisely what causes the eyes of negotiators on the Mercosur side of the table to sparkle:

[W]orldwide, the CGG countries are the third largest destination of the [Mercosulian] agribusiness exports, behind China and the United States. If we take Brazil as an example, the GCC is the second largest destination of Brazilian agribusiness exports, only behind China (CCAB 2018).

Food security measures in the GCC such as investment in farmland and poultry farming around the world cross the Indian and Atlantic oceans and reach South America driven by sovereign wealth funds (SWFs). In 2011, Hassad Food, the agricultural investment arm of Qatar Investment Authority, 'announced its intention of investing \$100 billion in grain production in Argentina' (Viramontes 2012: 41). Hassad Food has also been 'evaluating possible purchases of assets in the sugar and poultry sectors in Brazil, as problems in these industries have been creating opportunities in the country' (Exame 2015). Still, the Saudi Agricultural and Livestock Investment Company holds $20 \%$ of the Brazilian slaughterhouse Minerva, while the Brazilian BRF and the Qatar Investment Authority have formed a joint-venture initiative to buy Banvit, the largest poultry producer in Turkey (CCAB 2018). Finally, the Al Gharrafa Investment Company, a subsidiary of the Qatar Holding LLC, has a 7\% share of Adecoagro, that, as of 2013, had at least '286,000 hectares of farmland and several industrial facilities distributed along the most productive regions of Argentina, Brazil, and Uruguay' (Cabrera 2018). ${ }^{10}$

On the one hand, Mercosur encompasses a space comprised by some of the world's largest food exporters. On the other, the GCC entails member states that import virtually all the food they consume. The match could not be more perfect. However, the relational constitution of space is always a contested process, given that 'the construction of one set 
of relations may involve both the exclusion of some entities (and their relations) as well as the forcible enrolment of others' (Murdoch 2006: 20). With regard to the KhaleejiMercosulian economic space, ${ }^{11}$ what makes the GCC more attractive to Mercosur is also, paradoxically, the biggest obstacle to the consummation of those relations: oil. The fact that petrochemicals have always been the main focus of interest in GCC exports to Mercosur (IDB 2009: 142) did not sensitize the Mercosulian negotiators, which excluded at least 195 articles of the petrochemical sector from the list of products to be negotiated in the conclusion of the free trade area. ${ }^{12}$ According to a representative of the Brazilian Ministry of Foreign Affairs' Trade Negotiations Division with the Middle East, Africa and Asia 'the advance in negotiations was braked by the complexity of dealing with goods and products related to oil and gas sectors, of offensive interest to the GCC and defensive to the Mercosur' (Souza 2018).

On behalf of the GCC, the Khaleeji negotiators blocked some of the Mercosur's most important products on its export agenda from joining the list of products to have their tariffs reduced/eliminated in the GCC-Mercosur Free Trade Area, such as meat and poultry. Even in the second stage of negotiations, when the lists of exceptions from both sides were reduced, the GCC still 'excluded 222 items from its offer, including meat, fish, dairy products, tobacco, ceramics for coverings, refrigerators, and iron and steel products' (IDB 2009: 142). Most of these products were of vital importance to the Mercosur side of the agreement.

It should be recalled that when a list of products for exclusion is made, delimiting what will be left out of a trade agreement, all production and supply chains organized to produce and distribute those products are, to a greater or lesser extent, also impacted. In this vein, the relations that constitute economic spaces are also (and obviously) relations of production; thus, what is included and what is excluded from the negotiation table will impact the overall space making process. It is fair to state that there is no point in constituting a free trade area if the products of utmost relevance to all parts involved are to be left out of the trade agreement. Instead of trying to overcome one of the greatest obstacles to the consolidation of the Khaleeji-Mercosulian commercial relations, that is, its over-concentration in commodities, or finding ways to integrate more value-added products into their trade-related deals (see CCAB 2020), negotiators on both sides chose to focus on limiting the number of products eligible for trade liberalization as much as they possibly could.

If the items covered by the GCC-Mercosur framework agreement are scarce, so are the actors who are entitled to play a role in this project. The accord makes it clear that the relations to be encouraged, promoted and privileged are those between exporters, investors, entrepreneurs, corporations and national agencies that foster trade and international investments. Expressions such as 'expansion and liberalization of trade relations,' 'deepening of exchange of information on foreign trade, 'promotion of capital flows' and 'facilitation of corporate investments' dominate the framework text of the agreement (GCCMERCOSUR 2005). As such, it clearly aims solely to stimulate the flow of goods and capital between the members of the two blocs and facilitate the mobility of the public and 
private economic agents linked to the export and investment sectors. However, a broader participation of civil society, agents and groups that reaches beyond economic actors and business associations is fundamental for the resumption of this agreement with more comprehensive and plural terms, in order for it to become more consistent with the building of a truly free trade area.

Within the context of the relational view of space that emphasizes the multiplicity in flows of people and ideas and networks of interest and cooperation, broader civil society participation could strengthen the perception that the GCC-Mercosur space is a space of numerous types of action. Barriers to trade and investment between the two blocs are much more likely to be eliminated when political and social actors of their member states trust each other more, and not just their economic actors, thereby promoting the consolidation of the agreement. In other words, the creation of cultural and inter-personal connections among civil society entities that are not necessarily linked to existing business interests, could subsequently further other economic and political goals.

This is exactly why the GCC-Mercosur agreement needs to be better divulged, debated and embraced by the societies that compose both blocs. There is a pressing need for the organization of congresses, conferences, symposiums and workshops that gather scholars from Mercosulian and Khaleeji universities so they can present their international political dilemmas, development challenges, and frustrations with international organizations to each other. Recent cultural shifts and possible points of convergence and divergence could also be brought to light between these Global South entities. One may wonder how many new intra-South connections could be forged by utilizing new technologies such as virtual seminars that gather social and political activists, scholars and practitioners to discuss, for example, the 'Economic, political and legal developments in Mercosur and the GCC: a comparative analysis' or 'Family farming and the production of organic products in Mercosur and the GCC: food security, water resource management and the agrarian question.' One might also ask how the GCC-Mercosur space would be decoded differently if there were the promotion of GCC literature and film festivals in Mercosur countries, and vice versa. The announcement and advertising of such events in official homepages, social media and networking sites, along with press releases in newspapers and magazines would create in the political imaginary of Mercosulian and Khaleeji societies the idea that there are things in common between them. It would also imprint the idea that the effort that is needed to expand and consolidate the GCC-Mercosur relations is worth the time investment it requires. By all means, this is only a suggestive argumentation, but this is one of the virtues of this case study as an in-depth study of a single unit that lends itself to this kind of illustrative inference derived from exploratory research (Gerring 2004).

Another complication for the evolution and consolidation of the GCC-Mercosur relations is that these are heavily concentrated in two countries only - Brazil and Saudi Arabia, and there are no provisions in the current framework agreement to alter this situation. In the three years immediately preceding the signing of the framework agreement (2003-2005), Saudi Arabia absorbed almost 90\% of all Mercosur imports. Brazil, correspondingly, accounted for at least $80 \%$ of all Mercosur exports to the GCC during 
the same period (Guimarães and Zeidan 2010). The latest available data shows that this reality has not changed much in recent years. To obtain a clearer idea of the concentration of Khaleeji-Mercosulian trade relations in Brazil and Saudi Arabia, I elaborated the table below, which shows the figures for GCC-Mercosur trade relations in 2018 by country, based on WITS data:

As Table 1 indicates, the total volume of Uruguayan exports to the GCC in 2018 reached around US\$ 20 million, while Paraguayan exports did not reach US\$ 90 million during that same year. Argentina, conversely, exported almost US\$1,4 billion to the GCC in 2018. Out of this amount, over US\$ 900 million was directed to Saudi Arabia alone. Brazil, on the other hand, exported almost US\$ 5,8 billion to the GCC in 2018 and more than US\$ 4 billion to two countries only: Saudi Arabia and the United Arab Emirates. Furthermore, out of the nearly US\$ 4,8 billion exported from the GCC to Mercosur in 2018, Saudi Arabia accounted for more than US\$2,5 billion. Finally, the destination of Saudi exports to Mercosur mainly aimed towards the Brazilian and Argentinian markets, with the balance leaning heavily towards the former. While Argentinian imports from Saudi Arabia in 2018 did not reach US\$ 204 million, Brazil imported over US\$2,3 billion worth of Saudi Arabian products. In sum, as of 2018, Brazil still accounted for almost $80 \%$ of all Mercosur exports to the GCC, of which Saudi Arabia still absorbed the largest share.

Table 1 - GCC-Mercosur trade in 2018 (imports and exports)

\begin{tabular}{lcccc}
\hline COUNTRY & $\begin{array}{c}\text { IMPORTS FROM } \\
\text { (US\$ Thousand) }\end{array}$ & $\begin{array}{c}\text { EXPORTS T0 } \\
\text { (US\$ Thousand) }\end{array}$ & $\begin{array}{c}\text { IMPORTS FROM } \\
\text { (US\$ Thousand) }\end{array}$ & $\begin{array}{c}\text { EXPORTS TO } \\
\text { (US\$ Thousand) }\end{array}$ \\
\hline BRAZIL & \multicolumn{2}{c}{ ARGENTINA } \\
\hline KUWAIT & $\$ 116,530.36$ & $\$ 416,175.11$ & $\$ 1,313.85$ & $\$ 8,032.94$ \\
\hline OMAN & $\$ 212,937.01$ & $\$ 227,277.10$ & $\$ 10,887.95$ & $\$ 128,621.20$ \\
\hline QATAR & $\$ 124,587.90$ & $\$ 674,666.12$ & $\$ 152,379.34$ & $\$ 73,131.47$ \\
\hline KSA* & $\$ 272,924.66$ & $\$ 267,856.70$ & $\$ 458,307.36$ & $\$ 24,611.01$ \\
\hline UAE** & $\$ 2,318,729.05$ & $\$ 2,107,636.94$ & $\$ 204,202.84$ & $\$ 931,899.34$ \\
\hline TOTAL & $\$ 561,443.50$ & $\$ 2,034,454.08$ & $\$ 137,890.44$ & $\$ 227,166.72$ \\
\hline BAHRAIN & $\$ 3,607,152.48$ & $\$ 5,728,066.05$ & $\$ 964,981.78$ & $\$ 1,393,462.68$ \\
\hline KUWAIT & - & URUGUAY & & PARAGUAY \\
\hline OMAN & $\$ 374.96$ & $\$ 1,662.80$ & $\$ 178.14$ & $\$ 2,153.77$ \\
\hline QATAR & $\$ 12,140.69$ & $\$ 2,317.72$ & $\$ 32,768.15$ & $\$ 5,469.42$ \\
\hline KSA* & $\$ 15,967.34$ & $\$ 2,078.26$ & $\$ 6,016.76$ & $\$ 1,655.91$ \\
\hline UAE** & $\$ 8,198.49$ & $\$ 2,884.89$ & $\$ 14,906.39$ & $\$ 21,425.50$ \\
\hline TOTAL & $\$ 9,385.84$ & $\$ 8,091.96$ & $\$ 187,635.51$ & $\$ 32,559.56$ \\
\hline & $\$ 46,067.59$ & $\$ 20,338.67$ & $\$ 241,504.95$ & $\$ 88,686.75$ \\
\hline
\end{tabular}

*KSA: Saudi Arabia **UAE: United Arab Emirates - No significant trade reported Source: Created by the author based on data from the World Integrated Trade Solution (2019). 
However, this perceived excessive concentration of GCC-Mercosur relations in Brazil (and to a lesser extent, in Argentina) and Saudi Arabia has to be put into perspective. Brazil and Argentina combined 'account for about 95 percent of both the bloc's GDP and population' (Felter et al 2019). The Brazilian state of São Paulo alone has more inhabitants than Argentina, and Brazil's GDP accounts for more than 75\% of Mercosur's total GDP. Likewise, Saudi Arabia's population is estimated at over 34 million people, a number equivalent to almost $60 \%$ of the total GCC population and its GDP corresponds to nearly $50 \%$ of the total Khaleeji GDP (World Bank 2019).

If GCC-Mercosur trade is strongly marked by the preponderance of the two largest countries within each respective bloc (Saudi Arabia and Brazil), as far as investments are concerned, the numbers are disheartening. During the 2003-2015 period, for instance, not a single Mercosulian state ranked in the list of the 30 largest recipients of Saudi, Emirati, Qatari or Kuwaiti investments, according to data provided by the Arab Investment \& Export Credit Guarantee Corporation (2015). The first Arab country to appear on the FDI list as one of the largest receivers of investments in Latin America (Brazil) was the United Arab Emirates (UAE), in 2015, ranking 55 $5^{\text {th }}$.

In other words, the GCC invests very little in Mercosur. This is probably due to a lack of any bilateral investment agreements in place, considering that only Argentina and Qatar have recently signed a bilateral agreement on double taxation (DTA) and that there are no other arrangements of this nature in place between any member state of the two regions (The Economist Intelligence Unit 2016: 7). Lastly, the blocs lack a minimally developed financial structure to stimulate investment from the Gulf into Mercosur. Only the Brazilian banks Banco Itaú and Branco do Brasil have small representative offices in Dubai and there are no Arab banks represented in any Mercosulian country (EMIA 2014).

\section{Conclusion}

This article has framed the GCC-Mercosur agreement within a broader discussion on how the South is enacted through South-South relations, using it as a case study of the obstacles involved in the making of spaces within the Global South. Comprehending why some Southern spaces fail to materialize allows us to envision alternatives and ways to overcome these impediments. According to the theoretical provisions of relational space proposed by Harvey, Massey and Murdoch, spaces are constituted and manifested in the multiplicity of their relations. Building on this approach, I have hereby inferred that it is through the multitude and plurality of actors, entities and processes that space is in fact constituted, thus demanding a broader participation of civil societies in the processes of Global South space making.

The findings of this research demonstrate that the GCC-Mercosur framework agreement is limited in scope and depth and that the entities and processes connected to it are scarce. Therefore, even if the Arab-Brazilian Chamber of Commerce vehemently maintains that 'the agreement has not been signed effectively, but it cannot be said that it has been abandoned' (CCAB 2018), the fact of the matter is that the processes that created the 
GCC-Mercosur economic space have not been able to sustain it. Moreover, if efforts are not made to address the causes of the paralysis of negotiations, this space will eventually be dissolved.

From the standpoint of the relational view of space, if the GCC-Mercosur space comes to 'flicker out of existence' in the expressive words of Nigel Thrift (2004: 91) this could be due to a few reasons, namely the constitution of exceptions lists that exclude key products out of the trade relations; the excessive concentration of relations, mostly between only two countries (Brazil and Saudi Arabia); the absence of mechanisms capable of attracting much-desired investments from the Gulf sovereign wealth funds into Mercosur; the limitation of the objectives of economic cooperation to the mere stimulation of the flow of goods and capital between the two blocs; and the exclusivity of facilitating relations between economic agents linked only to export and investments sectors, leaving out key sectors of civil society that could otherwise contribute to the development of the project.

Regrettably, the rewards that could come from the consolidation of the GCC-Mercosur economic space are very tangible and include the possibility of fostering more diversified trade, more access to foreign direct investment, more varied partners for knowledge and information exchange, and an increased capacity to act assertively in certain areas of world politics. In this sense, a large free trade area between two blocs located in two developing regions could represent leverage in terms of promoting local and regional economic development, sustainable agricultural growth, and reciprocal support in multilateral fora to reduce economic inequalities between North and South. These could be among the objectives of the GCC-Mercosur agreement, but they are not.

The narrowness in the founding terms of the GCC-Mercosur economic space significantly reduces the possible plurality of their relations; yet it is in the multiplicity of relations that space is constituted and manifested. By narrowing down the scope of what is considered as economic cooperation, the agreement excluded whole sets of relations that might have given the GCC-Mercosur space some kind of spatial coherence or, in Harvey's terms, a measure of permanence. Organized civil society beyond business organizations, such as political parties, NGOs, social movements, trade unions, universities and research centres are just some examples of the entities that are, in principle, excluded from the GCC-Mercosur space making process, as they are not even mentioned in the framework agreement. These entities and their interrelations, interactions and correlations could vastly broaden the range of the Khaleeji-Mercosulian relations, rendering this space meaningful beyond the narrow scope of business as usual. However, as it has been constituted, the GCC-Mercosur agreement restricts access more than it promotes inclusion, which says a lot about space making in the Global South.

As long as South-South relations remain a state-only endeavour, carried out mostly by heads of state, their foreign ministries, and business associations to a greater or lesser extent connected with governmental agents, the spaces of the South will not consolidate. The GCC-Mercosur agreement is a top-down process that lacks developed mechanisms to enable and encourage the engagement of the societies that are forcibly subject to its decisions, and that, as such, should have a say in its outcomes. Space making in the Global South is about connecting the local, the national, the regional, the interregional and the 
global scales - a task that unavoidably requires the engagement of the civil societies from the Global South. If the failure of the GCC-Mercosur agreement to materialize into a meaningful economic space can teach us anything, this would be its most elementary lesson.

\section{Notes}

1 For a literature review on the Arab-Latin American relations, with a special focus on political economy, see Funk (2016).

2 BRICS (Brazil, Russia, India, China and South Africa); MINT (Mexico, Indonesia, Nigeria and Turkey); CIVETS (Colombia, Indonesia, Vietnam, Egypt, Turkey and South Africa); and Next-11 (Bangladesh, Egypt, Indonesia, Iran, Mexico, Nigeria, Pakistan, the Philippines, Turkey, South Korea and Vietnam).

3 For Mignolo (2014), 'the configuration of the BRICS states is of extreme relevance [...] because, among other reasons, it dismantles "East/West" and "North/South" divides.'

4 'Space is about materiality and the life that animates it' (Santos 1996: 51).

5 For a decolonial critique of the concept of Global South, see Mignolo (2014).

6 On the asymmetries among Southern countries and the indispensability of analyzing the power relations among them, with a particular reference to the investigation of the relationship between Brazil and Mozambique, see Seifert (2020).

7 On non-representational theory, see Thrift (2008).

8 For an assessment of the role of the GCC states in the framework of Global South studies, see Ulrichsen (2013). For a critique of GCC investments in the Arab and Muslim worlds, see Hanieh (2011). For a thorough analysis of how GCC capital is shaping the political economy of the wider Middle East, see Hanieh (2018).

9 Venezuela was admitted to Mercosur in 2012, but was suspended from the bloc in 2016.

10 On GCC foreign agro-investments, see Woertz (2013).

11 'Khaleej' is an Arabic word for 'Gulf' and 'khaleeji' is its adjective. Both are chiefly associated with the Arab Gulf States and its peoples.

12 From an original list of exceptions of 1,600 products, Mercosur reduced its list down to 534 items in the second stage of negotiations (195 being from the petrochemical sector). The final reduction offered by the GCC at this second (and, as of 2020, last) stage still excluded 222 items from the original offer.

\section{References}

Alden, C, S Morphet and M A Vieira. 2010. The South in World Politics. New York: Palgrave Macmillan.

Ayuso, A, S Villar, C Pastor and M Fuentes. 2018. 'Actors and Opportunities: Interregional Processes Between the Arab Region and Latin America and the Caribbean.' In F Mattheis and A Litsegård. (eds), Interregionalism across the Atlantic Space. Cham: Springer, pp. 51-74.

Bergamaschi, I, P Moore and A B Tickner (eds). 2017. South-South Cooperation Beyond the Myths: Rising Donors, New Aid Practices? London: Palgrave Macmillan.

Braveboy-Wagner, J A. 2009. Institutions of the Global South. Abingdon: Routledge. . 2016. Diplomatic Strategies of Nations in the Global South: The Search for Leadership. New

York: Palgrave Macmillan. 
Britannica. n.d. 'Encyclopedia Britannica | Britannica.' At https://www.britannica.com [Accessed on 12 November 2020].

Brun, E. 2015. 'Between Dynamism and Dispersion: The Four Pillars of Latin American Foreign Policies towards the Middle East.' In E Brun and R Khatlab (eds), Latin America and the Middle East: Crossed Perspectives. Beirut: USEK, pp. 19-41.

Cabrera, A. 2018. Adecoagro - One of the largest agricultural companies in South America. At https:// www.gatewaytosouthamerica-newsblog.com/adecoagro-one-of-the-largest-agricultural-companies-in-south-america/ [Accessed on 18 November 2018].

Arab-Brazilian Chamber of Commerce (CCAB). 2018. Interviewed by the author, 18 December.

. 2020. Webinar - Brasil \& Países Árabes: Diplomacia Econômica/ Brazil and Arab Countries:

Economic Diplomacy. At https://zoom.us/webinar/register/WN_d-ryKLqZQSuMeDfsFrDZ5w [Accessed on 24 June 2020].

Cheru, F. 2016. 'Emerging Southern powers and new forms of South-South cooperation: Ethiopia's strategic engagement with China and India.' Third World Quarterly 37 (4): 592-610.

Dargin, J (ed). 2013. The Rise of the South. Philosophical, Geopolitical and Economic Trends of the 21st Century. Singapore: World Scientific Publishing.

The Arab Investment \& Export Credit Guarantee Corporation. 2015. Investment Climate in Arab Countries: Dhaman Investment Attractiveness Index. Shuwaikh. At http://dhaman.net/en/wp-content/uploads/sites/3/2016/04/Climate-2015-English.pdf [Accessed on 20 April 2017].

Emerging Market Investor's Association (EMIA). 2014. Building A Bridge to the Middle East. At http://www.emia.org/news/story/2184 [Accessed on 6 February 2018].

Exame [online]. 2015. 'Hassad Food avalia ativos de açúcar e aves no Brasil.' 25 February. At https:// exame.abril.com.br/negocios/hassad-food-avalia-ativos-de-acucar-e-aves-no-brasil/ [Accessed on 21 November 2018].

Farah, P D E. 2014. 'The summit of South America-Arab States: historical contexts of South-South solidarity and exchange.' In P Amar (ed), The Middle East and Brazil: perspectives on the new global South. Bloomington: Indiana University Press, pp. 39-56.

Felter, C, D Renwick and A Chatzky. 2019. Mercosur: South America's Fractious Trade Bloc. Council on Foreign Relations [online]. At https://www.cfr.org/backgrounder/mercosur-south-americas-fractious-trade-bloc [Accessed on 6 November 2019].

Ferabolli, S R. 2017. 'Regions that matter: the Arab-South American interregional space.' Third World Quarterly 38 (8): 1767-1781.

. 2019. 'Do the Arab Gulf States belong to the South?' Mundorama: Divulgação Científica em Relações Internacionais.

Foucault, M. 1982. The Archeology of Knowledge. New York: Pantheon Books.

_. 2003. 'Society Must Be Defended': Lectures at the Collège de France, 1975-1976. New York: Picador.

2020. 'The Order of Discourse.' In R Young (ed), Archives of Infamy. London: Routledge; Boston: Kegan Paul, pp. 141-174.

Funk, K. 2016. 'How Latin America Met the Arab World: Toward a Political Economy of Arab-Latin American Relations.' In M T Kuri (ed), Latin American Foreign Policies towards the Middle East: Actors, Contexts, and Trends. New York: Palgrave Macmillan, pp. 11-36. 
Galindo, A (ed). 2013. The Gulf and Latin America: An Assessment of Expectations and Challenges. Cambridge: Gulf Research Centre.

GCC-MERCOSUR. 2005. Framework Agreement on Economic Cooperation Between the Member States of the Cooperation Council for the Arab States of the Gulf and the Member States of MERCOSUR. At www.sice.oas.org/TPD/MER_GCC/Negotiations/acordomercosul_ccg_e.doc [Accessed on 18 September 2018].

Geddes, B. 1990. 'How the Cases You Choose Affect the Answers You Get: Selection Bias in Comparative Politics.' Political Analysis (2): 131-150.

Gerring, J. 2004. 'What is a case study and what is it good for?' American Political Science Review 98 (2): 341-354.

Gray, K and B K Gills 2016. 'South-South cooperation and the rise of the Global South.' Third World Quarterly 37 (4): 557-574.

Grovogui, S. 2011. 'A revolution nonetheless: the global south in international relations.' The Global South 5 (1): 175-190.

Guimarães, E P and R M Zeidan. 2010. Acordos do Mercosul com terceiros países. Texto para Discussão No. 1541. At http://hdl.handle.net/10419/91376 [Accessed on 18 January 2018].

Hanieh, Adam 2011. Capitalism and class in the Gulf Arab states. New York: Palgrave Macmillan. 2018. Money, markets, and monarchies: the Gulf Cooperation Council and the political economy of the contemporary Middle East. New York: Cambridge University Press.

Harvey, D. 1973. Social Justice and the City. Athens: University of Georgia Press.

1996. Justice, Nature and the Geography of Difference. Oxford: Blackwell.

2004. Space as a key word. Paper delivered at Marx and Philosophy Conference. London, UK. At http://frontdeskapparatus.com/files/harvey2004.pdf [Accessed on 20 April 2018].

Hubert, C. 2017. Food security: The Gulf Cooperation Council states in dire straits. Global Risk Insights [online]. At https://globalriskinsights.com/2017/07/food-security-gulf-cooperation-council-states/ [Accessed on 13 November 2018].

Hurrell, A. 2013. 'Narratives of emergence: Rising powers and the end of the Third World?' Brazilian Journal of Political Economy 33 (2): 203-221.

Inter-American Development Bank (IDB). 2009. MERCOSUR Report N. 13, May 2009. Buenos Aires. At http://www.sciencespo.fr/opalc/sites/sciencespo.fr.opalc/files/i_mercosur_report_13\%5B1\%5D. pdf [Accessed on 16 September 2017].

Internet Geography. n.d. ' GCSE Geography Resources - Internet Geography - AQA - EDEXCEL OCR.' At https://www.internetgeography.net [Accessed on 12 November 2020].

Massey, D. 1999. 'Philosophy and politics of spatiality: some considerations. The Hettner-Lecture in Human Geography'. Geographische Zeitschrift 87 (1): 1-12.

2005. For Space. London: Sage Publications.

Mignolo, W D. 2014. 'The North of the South and the West of the East. A Provocation to the Question. Ibraaz Contemporary Visual Culture in North Africa and the Middle East 8. At https:// www.ibraaz.org/essays/108 [Accessed on 20 November 2020]. 
Ministry of Foreign Affairs [Brazil]. 2015. IV Cúpula ASPA - América do Sul Países Árabes. At http:// blog.itamaraty.gov.br/181-iv-cupula-aspa-america-do-sul-paises-arabes-em-riade-arabia-saudita [Accessed on 10 January 2016].

Muhr, T. 2016. 'Beyond 'BRICS': ten theses on South-South cooperation in the twenty-first century' Third World Quarterly 37 (4): 630-648.

Murdoch, J. 2006. Post-structuralist Geography: Guide to Relational Space. London: Sage Publications.

Pinto, V C. 2016. 'Latin America and the Gulf: Assessment of Current and Future Trend'. In C Koch and H T Ibrahi (eds), Gulf Yearbook 2015 - 2016. Jeddah: Gulf Research Centre, pp. 1-18.

Rich, T S and S Recker. 2013. 'Understanding Sino-African relations: Neocolonialism or a New Era?' Journal of International and Area Studies 20 (1): 61-76.

Said, E W. 1978. Orientalism. London: Routledge and Kegan Paul.

Santos, M. 1996. A natureza do espaço: Técnica e tempo, razão e emoção. São Paulo: Edusp.

Seifert, J. 2020. Power and Horizontality in South-South Development Cooperation. The Case of Brazil and Mozambique. Berlin: Logos Verlag Berlin.

Sophia, M. 2015. 'Food Security: Should The GCC Be Worried?' Gulf Business [online], 14 March 2015. At https://gulfbusiness.com/food-security-gcc-worried/ [Accessed on 13 November 2018].

Souza, E T. 2018. Interviewed by the author. 5 December.

Stuenkel, O. 2013. Institutionalizing South-South Cooperation: Towards a New Paradigm? Post Western World. At https://www.postwesternworld.com/2013/05/31/institutionalizing-south-southcooperation-towards-a-new-paradigm/ [Accessed on 20 April 2018].

Terterov, M, M Vallet and C Nocente. 2013. 'Searching for an End Game in the West's Unwinnable Wars in the South: The Experience of Counter-Terrorism Strategies in a Selection of Muslim Countries.' In J Dargin (ed), The rise of the global south: Philosophical, geopolitical and economic trends of the 21st century. Singapore: World Scientific Publishing, pp. 213-244.

The Economist Intelligence Unit. 2016. 'Bridging the Gulf: LatAm-GCC trade and investment'. The Economist [online]. At https://perspectives.eiu.com/sites/default/files/EIU-Dubai\%20Chamber\%20 Bridging\%20the\%20Gulf\%2027th\%20October\%202016.pdf [Accessed on 6 February 2018].

Thrift, N 2004. 'Summoning life.' In P Cloke, P Crang and M Goodwin (eds), Envisioning human geographies. London: Routledge, pp. 81-103.

2008. Non-Representational Theory: Space, Politics, Affect. Non-representational theory: Space, politics, affect. London: Routledge.

Ulrichsen, K C. 2013. 'The gulf states and South-South cooperation.' In J Dargin (ed), The rise of the global south: Philosophical, geopolitical and economic trends of the 21st century. Singapore: World Scientific Publishing, pp. 153-174.

Viramontes, E. 2012. 'The role of Latin America in the foreign policies of the GCC states.' 3rd Gulf Research Meeting.

Woertz, E. 2013. 'The Governance of Gulf Agro-Investments.' Globalizations 10 (1): 87-104.

Woods, N. 2008. 'Whose aid? Whose influence? China, emerging donors and the silent revolution in development assistance.' International Affairs 84 (6): 1205-1221.

World Bank. 2019. World Bank Open Data. At https://data.worldbank.org [Accessed on 4 February 2020]. 


\title{
About the author
}

Silvia Ferabolli is a Lecturer in the Department of Economics and International Relations at the Federal University of Rio Grande do Sul (UFRGS) in Brazil. She holds a Ph.D. in Politics and International Studies from the School of Oriental and African Studies (SOAS) at the University of London. Her main publications include Arab regionalism: a post-structural perspective (Routledge Studies in Middle Eastern Politics 2014, hardcover; 2016, paperback), Relações Internacionais do Mundo Árabe: os desafios para a realização da utopia pan-arabista (Juruá $1^{\text {st }}$ ed., 2009; $2^{\text {nd }}$ ed., 2013) and 'Regions that matter: the ArabSouth American interregional space' (Third World Quarterly, 2017). She is the current Coordinator of the Graduate Programme in International Strategic Studies at UFRGS.

\section{Construindo Espaços no Sul Global: Lições do Acordo GCC-Mercosul}

\begin{abstract}
Resumo: Este artigo propõe uma abordagem revisada da definição e compreensão do termo 'Sul Global,' ancorando seu significado em uma visão relacional do espaço. Em segundo lugar, o artigo apresenta o acordo GCC-Mercosul como um caso de estudo dos obstáculos envolvidos na formação de espaços no Sul Global. A principal questão de pesquisa abordada aqui é: Por que o acordo-quadro GCC-Mercosul não se materializou em um espaço econômico significativo? Por meio dos insights teóricos de David Harvey e da abordagem relacional do espaço de Doreen Massey, bem como da geografia pós-estrutural, esse artigo argumenta que a promessa de maior comércio e investimento foram as bases sobre as quais o espaço econômico do CCG-Mercosul foi projetado, mas que o estreito escopo do acordo-quadro e as relações sociopolíticas organizadas em torno dele não têm sido capazes de sustentar ou fortalecer este espaço do Sul Global. Esse estudo tem como principal técnica metodológica a análise do discurso, fundamentada em uma compreensão foucaultiana das propriedades empíricas das atividades discursivas. Conclui defendendo a necessidade de incentivar um envolvimento mais amplo da sociedade civil nos processos de construção espacial do Sul Global.
\end{abstract}

Palavras-chave: Sul Global; espaço relacional; Acordo GCC-Mercosul; relações SulSul; relações Árabe-Latino-americanas.

Received on 30 April 2020, and approved for publication on 8 October 2020.

\section{(cc) BY-NC} https://creativecommons.org/licenses/by-nc/4.0/ 